\title{
The Beaver and the Bear: Canadian Mutual Aid, Ship Repairing and the Soviet Far Eastern Merchant Fleet 1941-1945
}

\section{James Pritchard}

\begin{abstract}
L'Union Soviétique, avec la seule exception de la Grande-Bretagne, est devenu le plus important bénéficiaire de l'aide mutuelle canadienne pendant la deuxième guerre mondiale. La quasi-totalité de cette aide a été transportée par des navires portant pavillon soviétique de Vancouver à Vladivostok et à d'autres ports de la Sibérie. Les réparations de ces vaisseaux étaient un dispositif unique de cette aide. Les espoirs canadiens que l'aide mutuelle mènerait à des relations commerciales plus durables dans la période d'après-guerre sont tombés victimes aux soupçons et à l'hostilité américano-soviétique plutôt qu'aux abruptes révélations du déserteur Igor Gouzenko.
\end{abstract}

With the launch of Operation Barbarossa by Germany on 22 June 1941, the status of the Soviet Union vis-à-vis the countries comprising the United Nations was suddenly transformed from that of a not-wholly-disinterested neutral to that of a not-wholly-trusted ally. In any case, the opportunities and temporary relief afforded by the opening of an eastern front were not to be lost and it was immediately apparent that the West's new partner must be given immediate and considerable material assistance if she were to carry on the struggle - and indeed survive.

The role that Canada played in this vital undertaking, though not inconsiderable, remains largely unknown. Tentative at first and subordinated to British and American priorities, it came into its own with the passage in May 1943 of The War Appropriation (United Nations Mutual Aid) Act. During the next 28 months, many Soviet ships were repaired and serviced at Canadian west coast ports. One hundred and twenty-five vessels departed from Vancouver for Vladivostok and other Siberian ports with cargoes of Canadian flour, non-ferrous metals, chemicals, automotive parts and other industrial equipment. Ships were given as gifts and Soviet crews trained. This paper aims to describe and account for this significant Canadian contribution to victory; to assess its impact on the Canadian west coast ship repair industry; to examine its effect on Canadian-Soviet relations before and after the spy revelations in September 1945; and to consider the part it played in Canada's quest for peace in a post-war world increasingly dominated by mutual American-Soviet suspicion and hostility. 
At the outset of hostilities in 1939, and in keeping with British policy, Canada embargoed all exports to the Soviet Union including nickel and wheat, but was unable to meet London's request to intercept Soviet vessels bound for Vladivostok from American Pacific ports and search for contraband. ${ }^{1}$ After June 1941, both the embargo and trade inspection became irrelevant. Indeed, the press was quick to suggest that Canada was preparing to consider exporting wheat to the Soviet Union. ${ }^{2}$ During the depression, the Soviets had been buying up old ships that had been tied up for years in European and American ports and quickly put them to work in order to transport war supplies and stores to Far Eastern Soviet ports and develop a Pacific supply route. President Franklin D. Roosevelt had signed the Lend-Lease Act in March 1941 and later that year both the United States and Great Britain began providing arms, munitions, and civilian supplies to the Soviet Union pursuant to formal diplomatic agreements known as protocols. The first shipments began at the beginning of October. ${ }^{3}$

During 1941 and 1942, Canadian supplies were provided to the U.S.S.R. by diversions from British contracts in Canada. Shipment of Canadian cargoes was effected through the British Merchant Shipping Mission in the U.S. This was consistent with British desire to control shipping, as any direct dealing between Canada and the Soviet Union might divert ships from the United Kingdom. Thus, the first fifteen Canadian-built tanks left Canada for Vladivostok in October 1941. ${ }^{4}$ From then until 31 March 1944, Canadian supplies dispatched to Russia from the U.K. account included 1,388 Valentine tanks, 1,348 weapons carriers, 29 radar sets, 30,000 tons of aluminum and 27,000 tons of copper. ${ }^{5}$ Most supplies from Canada between July 1942 and June 1943 were shipped via the American eastern seaboard. ${ }^{6}$ By special Admiralty request, Canada also turned over the old icebreaker Montcalm to the Russians to help keep the ports of Murmansk and

1 Library and Archives Canada/ Record Group 25 (External Affairs)/ vol. 2,725/file 158-40 (pt.1) (hereafter LAC/ RG, followed by series, volume and file numbers) Exports to Soviet Union, war supplies, 1940-1941; also James Eayrs, In Defence of Canada (Vol. 2) Appeasement and Rearmament (Toronto: University of Toronto Press, 1965), 163-5 and 175.

$2 \quad$ E.g. "May Reopen Wheat Deal with Soviet," Winnipeg Free Press, 14 June 1941.

3 The literature on Allied aid to the Soviet Union is extensive, but see Alexander Hill, "British Lend-Lease Aid and the Soviet War Effort, June 1941-June 1942," The Journal of Military History, 71, 3 (July 2007), 773-808 for a valuable introduction to the changing historiography in the wake of the collapse of the U.S.S.R. and the opening of some Russian archives to foreign and Russian scholars.

4 Winston S. Churchill, The Second World War, Vol. 3, The Grand Alliance (Boston: Houghton Mifflin Co., 1951), 471. According to Hill, "British Lend-Lease Aid," 785 n36 30 Canadianbuilt tanks had reached the Soviet Union by 4 March 1942.

5 Canada, Report of the Canadian Mutual Aid Board (hereafter CMAB) 20 May 1943 to 31 March 1944 (Ottawa: King's Printer, 1944), 22-23 reports 1,223 Canadian-built tanks, but the number was later revised to 1,388; see LAC/ RG 25/ 2,526/ 158-40 (pt 4) Office of High Commissioner to N. A. Robertson, 15 April 1946.

6 Joan Beaumont, Comrades in Arms: British Aid to Russia 1941-1945 (London: DavisPoynter, 1980), 142. 
Archangel open for deliveries from the western Allies. ${ }^{7}$ The Soviet government gratefully accepted the gift. ${ }^{8}$ Wheat shipments were eventually financed by a three-year, mediumterm credit of $\$ 10$ million that Canada extended to the U.S.S.R. in September 1942. ${ }^{9}$ While covering wheat shipped primarily after the agreement was signed, the credit included all wheat and flour sent to the United Kingdom and diverted to the U.S.S.R. prior to 8 September 1942. It was exhausted in December 1943 after 772,269 bushels of wheat and 173,500 tons of flour had been delivered. ${ }^{10}$

American aid to the Soviet Union also began in October 1941. Although the United States and Great Britain reasoned that the Soviet Union's continuation in the war as an active and powerful ally was a fundamental condition of victory over Nazi Germany, the former had to be convinced the U.S.S.R. would survive the German attacks. Only after Roosevelt's emissary, Harry L. Hopkins, visited Moscow during the summer of 1941 and convinced the president that Russia would survive were U.S. state department and army advisors overruled and negotiations for lend-lease initiated. ${ }^{11}$ In order to make relations with the U.S.S.R. more palatable to the general public,

7 Built in 1904 at Glasgow, Scotland, by Napier and Miller, the Montcalm, 1,432 gross tons, became the workhorse of Canada's icebreaking fleet for the next 38 years before being transferred to the USSR. According to R. J. Fraser, "Early Canadian Icebreakers," Arctic, 16, 1 (March 1963), 4-5 she became a casualty of the "Murmansk run," but the Montcalm reached Russia and remained there throughout the war though serving as an Arctic stores ship rather than an icebreaker. Her name remained unchanged, and she reportedly transported political prisoners to the Gulag Archipelago beyond the Tajmyr Peninsula in August 1942 and again in the autumn of 1943 (see http://www.memorial.krsk.ru/eng.Dokumenty/ Sviget/Korolsks.htm).

8 LAC/ RG 28/ 256/ 196-13 D. B. Carswell to C. D. Howe, 28 May 1942; J. L. Black, Canada in the Soviet Mirror: Ideology and Perception in Soviet Foreign Affairs 1917-1991 (Ottawa: Carleton University Press, 1998), 132 dates the Soviet request as October 1942, which may refer to another request for icebreakers for the Montcalm reached Murmansk earlier during the summer in convoy PQ15.

9 Canada, Documents on Canadian External Relations (hereafter DCER), vol. 9, John F. Hilliker, ed. (Ottawa: Department of External Affairs, 1980), 442-4; Robert R. Bryce, Canada and the Cost of World War II: The International Operations of Canada's Department of Finance, 1939-1947 (Montreal and Kingston: McGill-Queen's University Press, 2005), 156.

$10 \mathrm{LAC/}$ RG 25/ 2,526/ 158-40 (pt 2) statement showing the Canadian exports to Russia by commodities during the period from September 11941 to August 31 1942; ibid. (pt 4) Credit agreement between Canada and the Union of Soviet Socialist Republics, London, 8 September 1942; ibid., C. F. Wilson to Oliver Master, acting deputy minister of trade and commerce, 20 June 1943. This was considerably in excess of the 139,000 tonnes of rolled oats, flour and grain acknowledged by Soviet historian Yu. G. Chernyavski to have been exported from Canada during the war (see Roger Munting, "Lend-Lease and the Soviet War Effort," Journal of Contemporary History, 19 (1984), 503).

11 Dwight William Tuttle, Harry L. Hopkins and Anglo-American Soviet Relations, 1941-1945 (New York \& London: Garland Publishing, 1983), 312; Robert N. Coakley, "The Persian Corridor as a Route for Aid to the USSR" in K. R. Greenfield, ed., Command Decisions (New York: Harcourt Brace \& Co., 1959), 154. 
Canadians, British and Americans began referring to the Soviet Union once it had become an ally as Russia. ${ }^{12}$

Two months after the U.S. extended lend-lease to the Soviet Union, the Japanese attacked Pearl Harbor and the subsequent declaration of war limited the number of American ships sailing to Vladivostok. ${ }^{13}$ Nevertheless, the United States directed the bulk of its enormous aid to the Soviet Union through the Soviet Far East. It is rarely appreciated that nearly half of all wartime Allied aid to Russia, more than double the tonnage shipped to Murmansk and Archangel, indeed, more than the combined shipments to those Arctic ports and the Persian Gulf reached the U.S.S.R. via Siberian ports, or that this aid was largely transported in Soviet-flagged vessels. ${ }^{14}$ The latter used the Siberian ports because the Soviet Union and Japan remained non-belligerents until the final days of the war. This Pacific route was not subject to a shortage of Allied shipping, then, but to the particular shortage of Soviet-flagged vessels that could sail through the La Perouse Strait past the Japanese islands of Hokkaido and the south part of Sakhalin to their destination. ${ }^{15}$ Hence, the urgent need to keep them operating and the growing number of

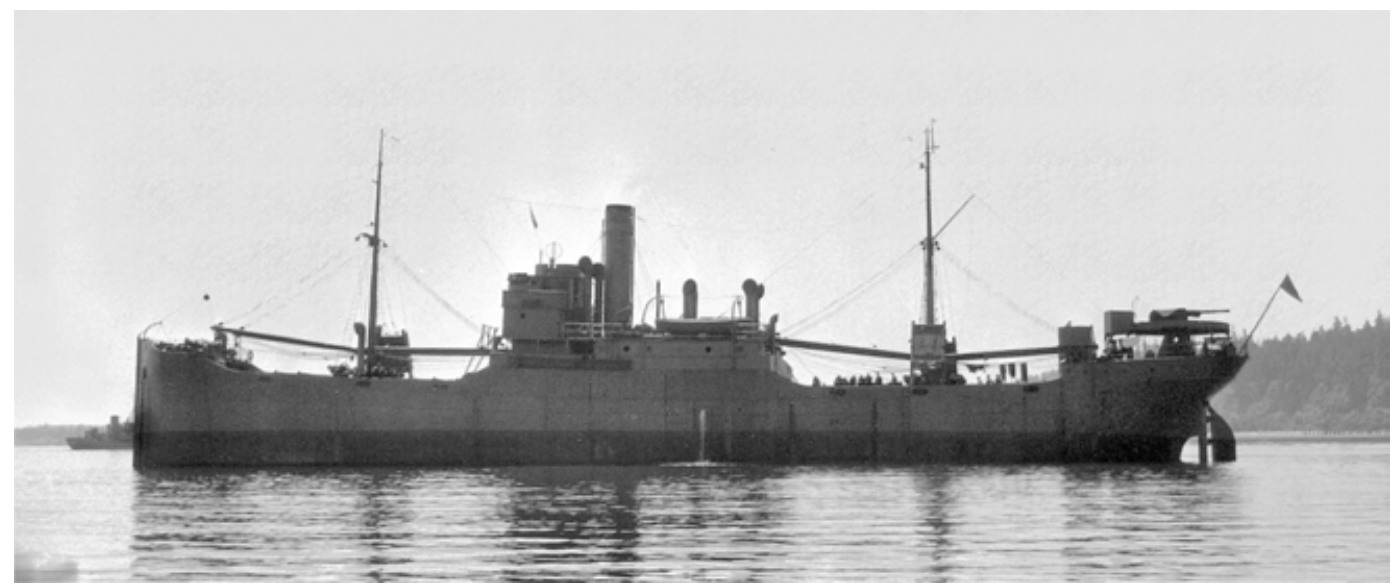

Illustration 1: A Canadian-built ship under the Soviet flag. SS Krasnoarmeets (Red Army) 2,222 gross tons, built by the Dominion Shipbuilding Company Ltd., Toronto, 1919 (exGeneral Williams, ex-Saga, ex-Certo), on 26 June 1942 in Vancouver harbour for repairs. Credit: Canada, Department of National Defence/ LAC/ e010783585.

12 Escott Reid, "Radical Mandarin:" The Memoirs of Escott Reid (Toronto: University of Toronto Press, 1989), 152.

13 Edward R. Stettinius, Lend-Lease: Weapon for Victory (New York: Macmillan, 1944), 203.

14 The greatest tonnage delivered to the Soviet Union, 9.2 million tons, reached Siberia from western US ports compared with 4.6 million tons shipped via the Persian Gulf and 4.4 million tons via Murmansk and Archangel. Much smaller amounts totalling 1.2 million tons entered via the Northern Sea Route and the Black Sea (see Robert Huhn Jones, The Roads to Russia: United States Lend-Lease to the Soviet Union (Norman: University of Oklahoma Press, 1969), 84; also Hubert P. Van Tuyll, Feeding the Bear: American Aid to the Soviet Union, 1941-1945 (Westport, CT: Greenwood Press, 1989), table 16, 164. 
Soviet ships appearing at Vancouver.

Soviet cargo ships began arriving at the Burrard Dry Dock Company's North Vancouver yard for refitting and deck stiffening and to have gunwale bars installed in March 1942. Initially funded under the American Lend-Lease Act, this work was carried out in Canada under the direction of the United States Maritime Commission in order not to interrupt the assembly-line approach to ship construction at the famous Kaiser yards to the south. ${ }^{16}$ Many American Liberty ships loan-leased to the U.S.S.R. also came to Vancouver for ice stiffening. ${ }^{17}$

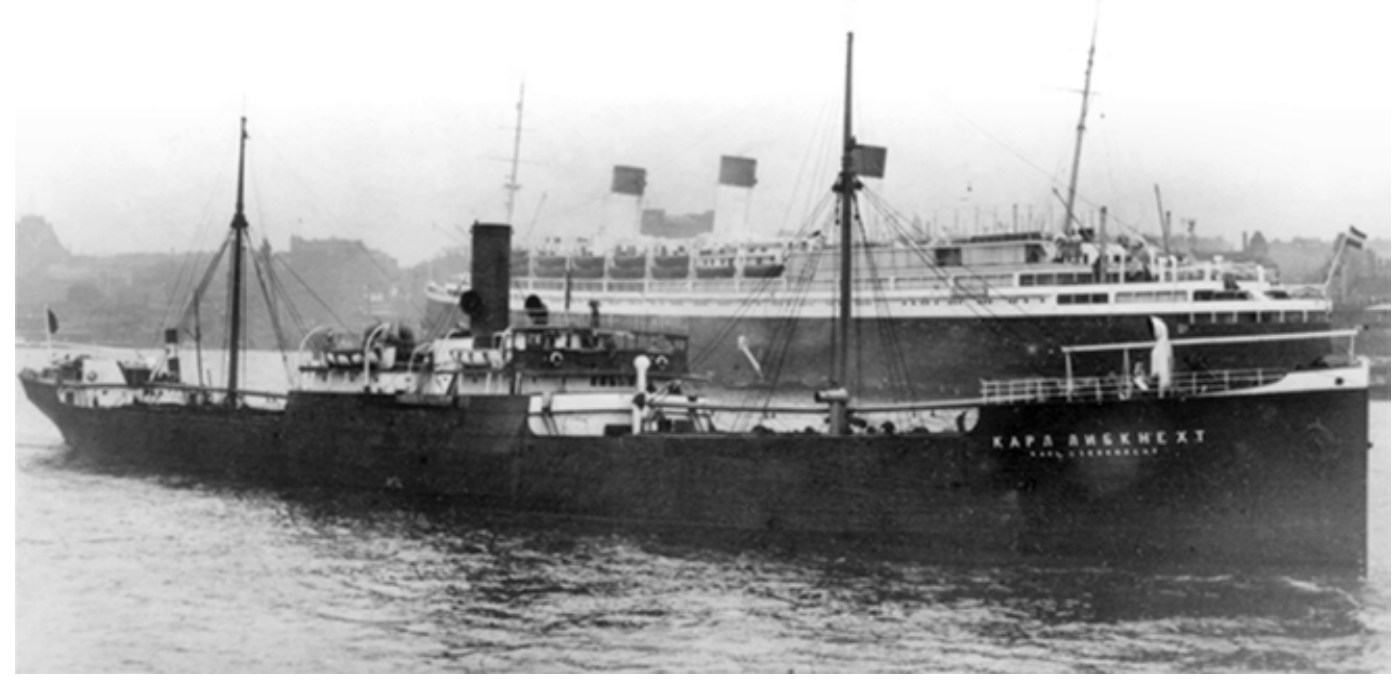

Illustration 2: SS Karl Liebknecht, built 1900, Keil, Germany, 3,341 grt, Captain Anna Shchetinina commanding. One of the first Soviet ships to arrive at Vancouver for repairs March 1942.

The first Soviet cargo ships, Krasnoarmeets and Karl Liebknecht, arrived for reconditioning at Burrard Dry Dock in March 1942. The next month, David Carswell, Canada's controller of ship repairs and salvage, discussed the situation in general with the Maritime Commission's engineer in Seattle and cooperated with the Americans to obtain materials. ${ }^{18}$ In June, the Klara Tsetkin was docked, and later that year the Sovetskaya Latvia was also repaired. ${ }^{19}$ The captain of the Liebknecht, Anna Shchetinina, caused a

16 LAC/ RG 28 (Munitions and Supply)/ 256/ 196-13-3 Report on ship repairs for the period ending May 31 $1^{\text {st }} 1942$; and Francis Mansbridge, Launching History; The Saga of Burrard Dry Dock (Madeira Park: Harbour Publishing 2002), 93.

17 On cracks in Liberty ships see Frederic C. Lane, Ships for Victory: A History of Shipbuilding under the U.S. Maritime Commission in World War II (Baltimore: The Johns Hopkins University Press [1951] 2001), 544-55.

$18 \mathrm{LAC/}$ RG 28/ 256/ 196-13-3 report on ship repairs and salvage for period ending May $31^{\text {st }}$ 1942.

19 Some confusion exists about the names of these ships. J. S. Marshall \& Co. Ltd., "History of 


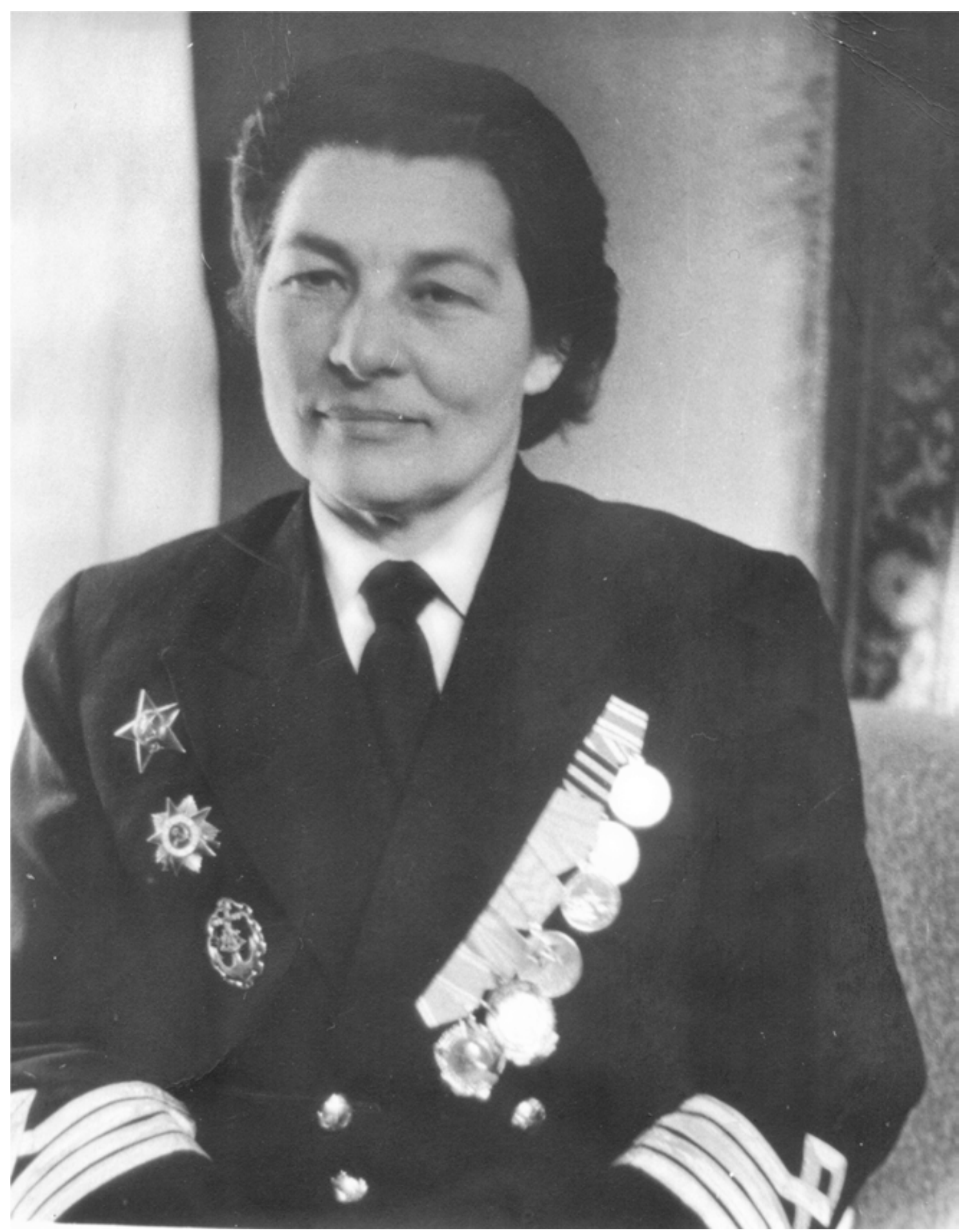

Illustration 3: Captain Anna Shchetinina in a post-war photo wearing her dress uniform of the Soviet Merchant Navy. Commanding one of the first Soviet ships to arrive in March 1942, she also commanded the Liberty ship, SS Jean Jaurès, which departed Vancouver three times with mutual aid cargoes between October 1943 and May 1944. Printed with the kind permission of the Vice Rector, Maritime State University, Vladivostok, Russia. 
sensation the first time she came ashore at Vancouver and briefly became the toast of the town. The world's first woman merchant ship captain, she crossed the Pacific seventeen times during the war. ${ }^{20}$ Early ship repair work caused no end of problems as officials with the U.S. Maritime Commission clashed repeatedly with the Soviets over the number of changes to be made. Later, Canadians were caught in the middle as the Russians appealed to Soviet officials at Ottawa. ${ }^{21}$

In addition to financing early repairs and conditioning, the U.S. began in January 1943 to transfer several newly built Liberty ships to the U.S.S.R. Eventually twenty-eight vessels, mainly Liberty ships, were delivered to the Soviet Union after first stopping at Vancouver where, for about $\$ 200,000$ per vessel, Burrard Dry Dock Company stiffened each hull and installed gunwale bars to overcome unexpected stress build-up in the welded steel hulls through contraction (and subsequent expansion) in the frigid waters of the North Pacific. ${ }^{22}$ Major cracks appeared in several American-built hulls, and several ships broke in half. ${ }^{23}$

The Valery Chkalov, a Liberty ship, met this fate in the Aleutians in mid-December 1943 while returning from Port Sovetskaya to the United States. She made maritime history of a sort when the bow section broke off, drifted in a half circle and rammed the aft part, becoming one of the few ships ever to collide with itself. ${ }^{24}$ The U.S. Navy eventually towed the ship's remains to Canada where the North Van Ship Repairs Company re-joined them in its dry dock in October $1944 .{ }^{25}$ On that occasion the company contracted with the U.S. War Shipping Administration

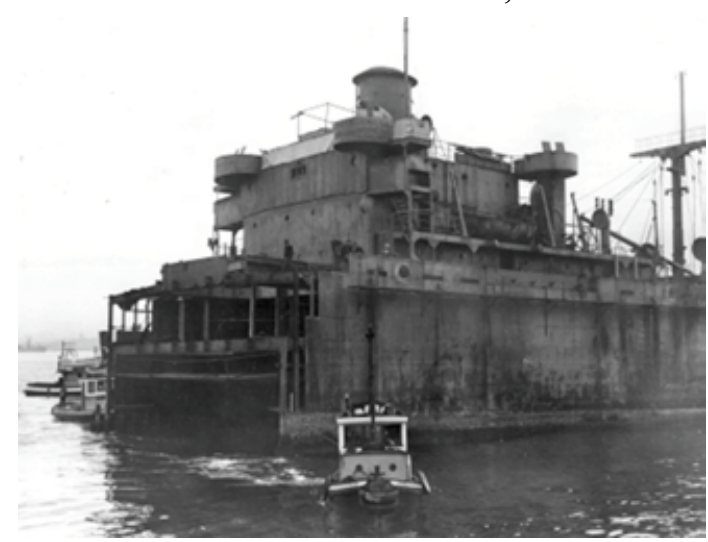

Illustration 4: Aft end of Liberty Ship SS Valery Chkalov being towed to North Van Ship Repairs c. September 1944. Photo by Betty Wardlaw. Credit North Vancouver Museum and Archives, photo 27-3625.

20 http://engforum.pravda.ru/archive/index.php/t-220734.html

21 Marshall "History of Burrard Dry Dock," 3: 193-4.

22 "Salvage Job For Russia," Canadian Shipping and Marine Engineering News (July 1944), 37 and 47. Mansbridge, Launching History, 93; on gunwale bars see Land, Ships for Victory, 555.

23 Leonard Arthur Sawyer and William Harry Mitchell, The Liberty Ships: The History of the 'Emergency' type Cargo Ships Constructed for the United States during World War II (Cambridge, MD: Cornell Maritime Press, 1970), 117 reported the John P. Gaines broke in two on 24 November 1943 during a storm in Alaskan waters.

24 Peter Elphick, Liberty: The Ships that Won the War (Annapolis: Naval Institute Press, 2001), 159 and 391 gives the 11th or 12th December 1943; also Sawyer and Mitchell, Liberty Ships, 133. Mansbridge, Launching History, 94 mistakenly reports the incident occurred in November 1944.

25 "Broken Liberty Ship Towed to City Shipyard For Repair," Vancouver Daily Province, 22 May 1944, 1; also "Salvage Job for Russians," 37. 


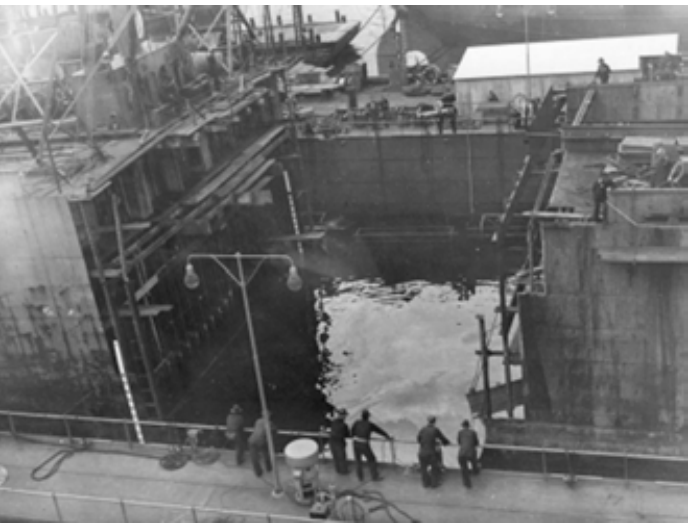

Illustration 5: Joining the two halves of SS Valery Chkalov, broken in half off Alaska, in dry dock of North Van Ship Repairs, photo by Betty Wardlaw, c. September 1944. Credit North Vancouver Museum and Archives, photo 27-3629. whose engineer inspector from the Seattle district maintenance and repair division supervised the work. The job was completed in just sixteen days, four fewer than promised. ${ }^{26}$ Re-named Alexander Baranoff, she entered the U.S. merchant fleet, for the Americans had already delivered a replacement Liberty ship, which the Soviets named Valery Chkalov II. This ship visited Vancouver in December. ${ }^{27}$

In all the United States transferred sixty-seven old cargo ships, including ten tankers, and forty-three new Liberty ships to the U.S.S.R.; fortyone of the Liberties spent the war years running between the western United States and Soviet Siberian ports. ${ }^{28}$ Accounts of American contributions normally omit any mention of the part played by Canada even though the first American transfer to the U.S.S.R. occurred on 20 November 1942, seven months after the first Russian vessel appeared at Vancouver for repair. There is no doubt that many Soviet-flagged ships ran between the U.S. west coast and Siberia (1,350 according to one source), but details concerning departures from Vancouver and repairs made there have received little notice. ${ }^{29}$

Even in late 1942, a full appreciation of Canada's role in the war was lacking. It became imperative that the King government devise a high profile sequel to its famous billion dollar gift made earlier to Britain. A bold new initiative was required if Canada was to continue financing domestic war production and raise her stature internationally. Rather than a junior partner of a beleaguered empire, Canada wanted to be acknowledged as one of the United Nations in her own right. A new arrangement was also essential to develop a sensible pattern of financial relationships with allied countries beyond the United Kingdom and the United States.

Following protracted discussions in the Department of Finance and the Cabinet War Committee, the Canadian Mutual Aid Board (CMAB) emerged as a product of the War Appropriation (United Nations Mutual Aid) Act that received vice-regal assent on 20

26 LAC/ RG 28/ 256/196-13-3 Report on ship repairs and salvage for period ending February $28^{\text {th }}$ 1943. Also see "Broken Ship Welded In Record Time Here," Vancouver Sun, 24 October 1944, 19.

27 Sawyer and Mitchell, Liberty Ships, 121 see under the Grant P. Marsh; also see LAC/ RG 36.21/ 76 cargo manifest.

28 Elphick, Liberty, 390-6.

29 Martin Bollinger, Stalin's Slave Ships: Kolyma, the Gulag Fleet and the Role of the West (Westport, CT: Praeger, 2003), 39. 
May $1943 .{ }^{30}$ With C. D. Howe, minister of munitions and supply, in the chair, and the four ministers of finance, agriculture, national defence and justice as members, the new board was one of the more important created during the war. ${ }^{31}$ Mutual aid under the act differed from previous Canadian aid in two respects. It was not confined to Great Britain, nor was it financial. Under mutual aid Canada dealt directly with other nations needing assistance and all aid was material. Canada supplied directly war supplies, food and industrial goods. ${ }^{32}$

The U.S. and U.K. provided war materials and civilian supplies to the U.S.S.R. pursuant to formal diplomatic agreements known as protocols. The second protocol spanning the twelve months beginning 1 July 1942 detailed the shipping tonnage to be made available for transporting stores and the amount of particular items to be provided. The amount of available shipping normally determined the volume of stores that the U.S.S.R. actually acquired. ${ }^{33}$ Canada announced its desire to participate in the third protocol to commence 1 July 1943, but being unable to provide shipping tonnage had to negotiate with American and British officials in Washington what form its contribution should take. ${ }^{34}$ During the summer, a Canadian advisory committee was set up in Washington to advise the Mutual Aid Board on allocations, and, in August, a CanadianAmerican joint aid committee was established to advise on coordinating allocations under Canadian mutual aid and U.S. lend-lease and to make recommendations to the CMAB concerning deliveries to non-empire countries including the U.S.S.R. ${ }^{35}$ As a consequence of these arrangements nearly three-quarters of Canadian exports to the U.S.S.R. during 1943 moved via U.S. ports. Total value of these exports was $\$ 57.7$ million, less than half of which was mutual aid. ${ }^{36}$ But this changed during the following year when Canada

30 For a brief outline of the mutual aid program see F. H. Soward, Canada in World Affairs, Vol. 4 From Normandy to Paris, 1944 to 1946 (London: Oxford University Press 1950), 74-80; also see Douglas H. Fullerton, Graham Towers and His Times (Toronto: McClelland and Stewart, 1986), 146-8; J. L. Granatstein, Canada's War; The Politics of the Mackenzie King Government, 1939-1945 (Toronto: University of Toronto Press, [1975] 1990), 311-13; and R. B. Bryce, Canada and the Cost of World War II, Matthew J. Bellamy, ed. (Kingston and Montreal: McGill-Queen's University Press, 2005),146-51.

31 Later, the minister of trade and commerce also joined the board. Although the board met weekly and spent more than $\$ 2.5$ billion, Howe's biographers make no mention of his chairmanship of this high spending board.

32 Canada, Report of the CMAB, 10.

33 Bryce, Canada and the Cost of World War II, 156.

$34 \mathrm{LAC/}$ RG 2, 7c (Privy Council)/ 12 (reel C-4,875) Cabinet War Committee minutes, 7 April 1943.

35 LAC/ RG 36.21 (Canadian Mutual Aid Board)/ 56/ 7-38 (p.3) vol.1 "Final draft of suggested arrangements for shipment of Canadian cargo to USSR via US ports and US cargo to USSR via Canadian ports." (n.d.); also C. P. Stacey, Men, Arms and Governments: The War Policies of Canada, 1939-1945 (Ottawa: Queen's Printer, 1970), 172.

36 Canada, Dominion Bureau of Statistics, Canada Year Book, 1945 (Ottawa: King's Printer, 1945), 497 and 505. 
became a direct party to the third protocol. ${ }^{37}$ A unique feature of mutual aid to the Soviet Union was that title of Canadian goods in transit was given to the Soviets immediately on leaving port owing to that country's non-belligerent status with respect to Japan and the need to prove ownership of what was being carried. ${ }^{38}$

The first mutual aid requisition for the Soviet Union was raised on 14 July 1943, and the first shipment of aluminum, other base metals and flour left Vancouver on board the freighter MV Komiles on 26 August. ${ }^{39}$ By the year's end, fifteen more Soviet ships had carried away 90,443 tons of Canadian mutual aid, chiefly wheat and flour, but also war supplies, the whole valued at $\$ 8,754,039 .{ }^{40}$ Among the ships was the Jean Jaurès, an American Liberty ship commanded by the celebrated Captain Anna Shchetinina, making one of her many wartime crossings of the Pacific. ${ }^{41}$ In addition, more than 10,000 long tons of American lend-lease material, largely auto parts, trucks and weapons carriers, were loaded on board ten of these freighters. Meanwhile, 5,441 tons of Canadian mutual aid material, chemicals and explosives worth $\$ 3,247,600$, left from US ports. ${ }^{42}$ Twelve more Soviet freighters departed from Vancouver before the end of the fiscal year, 31 March 1944. ${ }^{43}$

Under the third protocol Canada had committed to supply 300,000 tons of wheat and flour. Less than half the amount was shipped, however, because the country had exhausted its milling capacity to increase shipments to the Soviet Union. ${ }^{44}$ Up to 31 March 1944, Canada supplied the U.S.S.R. with about 13,700 tons of steel rails, 13,500 tons of aluminum, 11,700 tons of lead, 1,500 tons of nickel, 126,000 tons of flour and wheat, 2,400 tons of explosives and a wide range of industrial equipment, all worth just over $\$ 23$ million. $^{45}$

37 Canada, DCER, 9: 477-52 extract from the minutes of the cabinet war committee, 5 May 1943; and ibid. the third protocol, 11 May 1943.

$38 \mathrm{LAC/}$ RG 36-21/ 46 CMAB minutes, 13 August 1945.

$39 \mathrm{LAC} / \mathrm{RG} 25 / 2,526 / 158-40$ (pt 2) Karl C. Fraser, director of administration CMAB, to H. H. Wrong, undersecretary of state external affairs, 18 August 1943; and Canada, Report of the $C M A B, 21$. A Russian-built motor vessel, Komiles, 5,950 deadweight tons, was a veteran of the Murmansk convoys before being transferred to the Far East in 1943 when she was converted to carry railway locomotives.

$40 \mathrm{LAC/}$ RG 36.21/ 55/ 7-8 Sailings to USSR Carrying Mutual Aid Cargo, Ex. Vancouver BC, Revised list, 31 December 1943; LAC/ RG 25/ 2,526/ 158-40 (pt 3) "Sailings to the USSRCarrying Canadian Mutual Aid-ex. Vancouver, BC."

41 LAC/ RG 36.21/75 cargo manifest, the Jean Jaurès departed Vancouver on 23 October 1943, and in November, Captain Anna Shchetinina in command, was reported at PetropavlovskKamchatsky en route to Vladivostok. http://engforum.pravda.ru/archive/index.php/t220734.html.

42 LAC/ 36.21/ 55/ 7-8 (vol. 2) "1943 Tonnage Statement Lend Lease Material loaded at Vancouver," (n.d.)

$43 \mathrm{LAC} / \mathrm{RG} 36-21 / 75 /$ cargo manifests.

$44 \mathrm{LAC/}$ RG 25/ 2,526/158-40 (pt 3) G. R. Heaseman, CMAB, to H. H. Wrong, Assistant Undersecretary of State for External Affairs, 14 February 1944. 
Provision of repairs and services to Soviet ships in west coast ports was a unique feature of Canadian mutual aid to the U.S.S.R. Owing to the undesirability of withdrawing Canadian-built ships from the Allied pool of shipping, the Mutual Aid Board made no effort to transfer any vessels to the Soviet Union, but it did accede to a request that ship repairs be added to items in the third protocol. ${ }^{46}$ In addition to keeping Soviet vessels afloat, no matter how old, repairing them on the west coast before sending them back to sea to encounter ice when laden with Canadian war supplies made good sense.

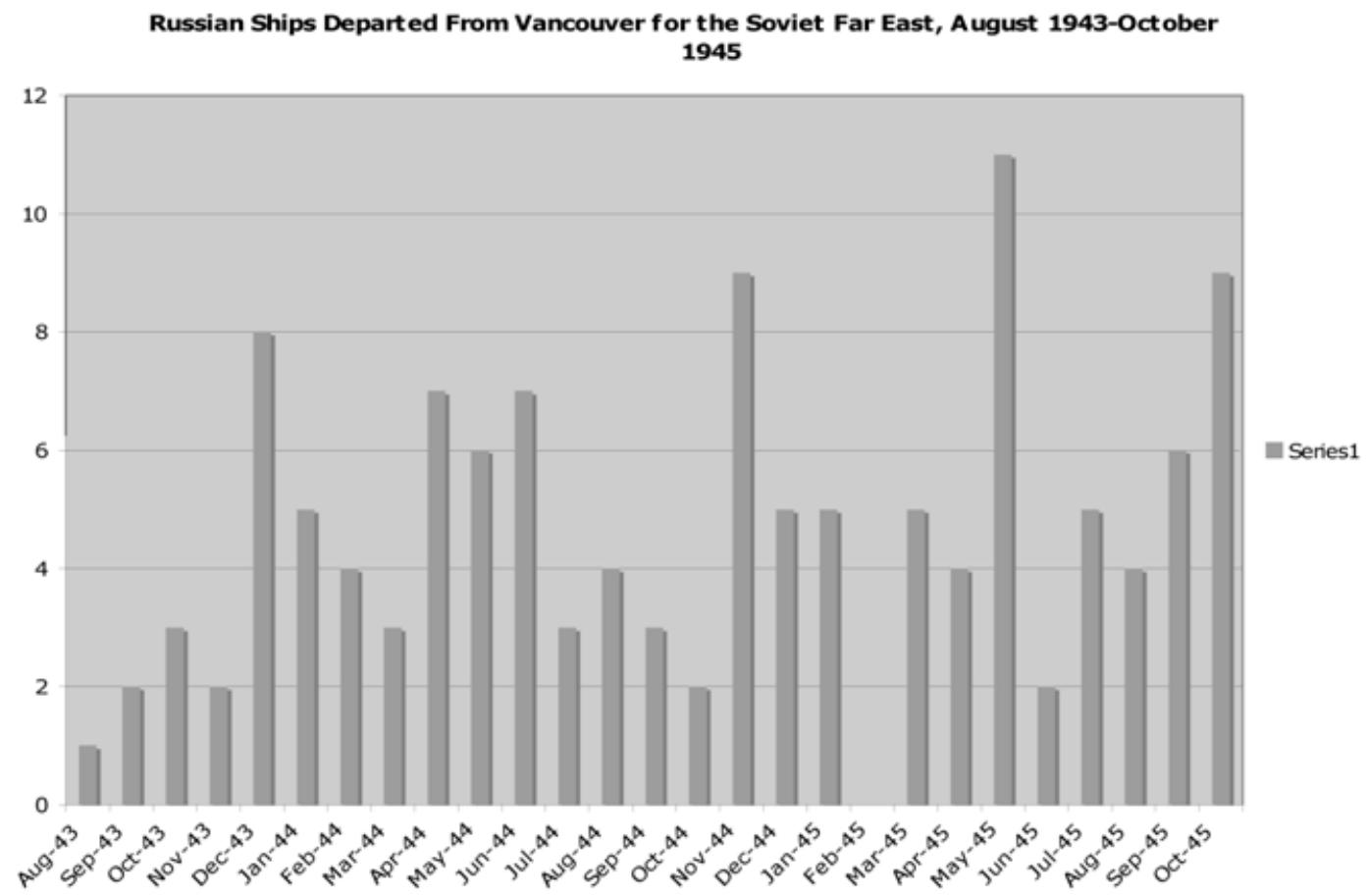

The bar graph above shows monthly departures of Soviet ships from Vancouver between August 1943 and October 1945. ${ }^{47}$ During the last five months of 1943, an average of three ships per month were present in Vancouver harbour either being serviced or loaded for Vladivostok and other Siberian ports. ${ }^{48}$ The steamships Desna and Dvina also entered the dry dock at Burrard Dry Dock Company for repairs after September when the Mutual Aid Board requested David Carswell to make repair services available to Soviet ships. The Board retained the Empire Shipping Company of Vancouver to act as its agent in carrying out repairs with the company reporting to Carswell in Montreal as

46 Ibid. / 46 CMAB minutes 4 and 28 June and 27 July 1943; RG 25/ 2,527/ 158-40 (pt 2) Canadian revised schedule of supplies to USSR during $3{ }^{\text {rd }}$ protocol, 3 August, including ship repairs.

47 Source for the graph is LAC/ RG 36.21/ volumes 75 to 80 containing 125 cargo manifests of Canadian mutual aid cargoes.

48 LAC/ RG 28/ 256/ 196-13-3 Report for January 1944, staff meeting, ship repairs and salvage control, 17 January 1943 (sic). 
repairs, servicing and victualling were carried out. ${ }^{49}$ The Vancouver branch of Wartime Merchant Shipping Limited, a crown corporation, assisted in allocating and supervising this work. A large number of vessels began taking advantage of Canadian ship repair, responsibility for which had been assumed from the Americans, and in March 1944, the corporation, now called Wartime Shipbuilding Limited, hired a Lloyds marine surveyor, R. M. Scott, to supervise the growing demand for work.

The Canadian government proved to be much better disposed towards the Soviets than the Americans, easier going and less doubting of Soviet motives. Although a majority of Canadians may have been suspicious, Ottawa appeared anxious to develop friendly diplomatic relations. This openness reflected the views of Dana Wilgress, former deputy minister of transport and Canada's new minister and later first ambassador to the Soviet Union. Wilgress's reports to Ottawa were much more sympathetic than others. ${ }^{50}$ Canada also had ambitions to develop postwar trade with the Soviet Union.

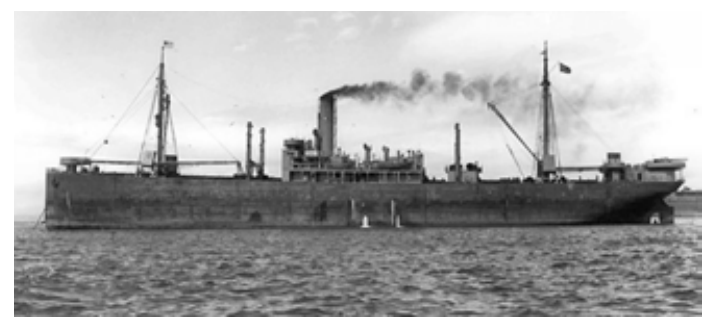

Illustration 6: SS Tashkent (ex-USS Iowan) transferred to USSR December 1942. Made five voyages from Vancouver to the Soviet Far East between November 1943 and March 1945.

Canadians experienced the same demands for repairs that had so frustrated the Americans before them. The age of the Soviet vessels, often 20 to 35 years old, meant that major refits were often necessary to make them seaworthy. ${ }^{51}$ During the eight months to 31 March 1944 (i.e. fiscal year 1943-1944), departures rose to 3.8 per month and Soviet ships received repairs and services worth $\$ 1,143,123 .^{52} \quad$ Carswell complained to C. D. Howe in February 1944 that Russian authorities were not well disposed towards his efforts to protect mutual aid funds. He estimated the average cost of a Soviet ship's visit to Canada to be about $\$ 60,000$ including handling, stevedoring, supplies and repairs. In addition, Russian engineers were calling upon mutual aid to strengthen new ships of welded construction (i.e. Liberty ships), essentially proposing they be rebuilt.

Cost estimates of the proposals amounted to $\$ 150,000$ per ship compared to the Canadian view that only $\$ 85,000$ worth of work needed to be done..$^{53}$ By the spring of 1944, repairs had assumed such substantial proportions on Canada's west coast that the controller of ship repairs found it necessary to call on Wartime Shipbuilding Limited to

49 LAC/ RG 36-21/ 46/ CMAB minutes 14 September 1943.

50 J. L. Granatstein, The Ottawa Men: The Civil Service Mandarins, 1935-1957, (Toronto: University of Toronto Press, [1982] 1998), 231-4. See also Denis Smith, Diplomacy of Fear: Canada and the Cold War 1941-1948 (Toronto: University of Toronto Press, 1988), 36-41.

51 LAC/ RG 28/ 18/ OF7-DMS History of Ship Repairs and Salvage Control.

52 Canada, Report of the CMAB, 22.

53 LAC/ RG 28/ 256/ 196-13-13(2) D. B. Carswell to C. D. Howe, 21 February 1944. 
assist in allocating, supervising and regulating maintenance work which had to be coordinated with new ship construction. Indeed, Carswell arranged with executives of Wartime Shipbuilding in Vancouver to handle the work. ${ }^{54}$

The Canadians refused to rebuild Liberty ships, less because they were hardnosed anti-communists than that the title to lend-leased ships remained with the U.S. Maritime Commission and that west coast ports had reached the limit of their capacity in repairing Soviet ships. If Liberty ships were rebuilt, repair capacity would be limited to four ships per month, but if such requests were denied, Canada could handle five or six ships per month. ${ }^{55}$

During the second full year of mutual aid, from April 1944 to March 1945, monthly ship departures increased as 56 ships left Vancouver, and the value of repairs and services supplied to Soviet vessels more than quadrupled to $\$ 4,843,000$. The number of ships that had to be dry-docked grew from two in 1943 to six in $1944 .{ }^{56}$ Canadian mutual aid to the Soviet Union totalled $\$ 97,633,000$, three times more than the previous year. The volume of food exports, wheat, flour, rolled oats and lard, 287,439 tons, was more than twice the previous year's total. Chemicals and explosives increased more than five times, and the 44,000 tons of steel rails were more than three times the previous year's shipment. As the Red Army fought its way across Europe, supply lines lengthened and it encountered demolition of railways, rolling stock and vehicles by retreating German armies. The U.S.S.R. had a gigantic transportation problem that Canadian shipments of rails, flat cars, military trucks, cranes and hoisting gear assisted in relieving. Other shipments provided raw materials and machine tools to Soviet factories. Alloy steel, zinc and ferro-silicon and ferro-chrome metals joined aluminum, nickel and lead that continued to be shipped as before.

Soviet demands continued unabated. During the eight months since it began to supervise repairs to Soviet ships, Wartime Shipbuilding Limited handled thirty-four vessels including three Liberty ships that were ice stiffened. Three ships from 23 to 31 years old received 210 days of general repairs worth approximately $\$ 700,000$. In November, the 26-year old icebreaker tug Dobrina Nikitich of Vladivostok underwent repairs estimated to cost $\$ 400,000$ and the SS Minsk, 28 years old, entered Victoria Machinery Depot shipyard for an overhaul worth an estimated $\$ 350,000 .{ }^{57}$ A later report suggested the work cost half a million dollars. ${ }^{58}$ In December, Wartime Shipbuilding identified nineteen additional ships scheduled for refit over the winter. One was the Liberty ship, Kuban, built in 1943, but seventeen were constructed before 1930 including

$54 \quad$ Ibid. / 3 report of ship repairs control for period ending April 301944.

$55 \mathrm{LAC/}$ RG 36.21/ 68/ 7-V3-A (p. 4) D. B. Carswell to G. R. Heasman, assistant to the director of administration, CMAB, 31 May 1944.

56 Marshall, "History of Burrard Dry Dock," 3: 193-4.

57 LAC/ RG 36.21/ 68/ 7-V3 vol. 10 (copy) Austin C. Taylor, vice president Wartime Shipbuilding Ltd. to C. D. Howe, 14 November 1944.

58 "Soviet Ship Arrives At Home Port After \$500,000 VMD Repair Job," Victoria Times, December, 1945, 13. 
one that was forty-five years old. ${ }^{59}$

Carswell responded to such heavy demands with a new policy. Henceforth, Soviet vessels arriving with work likely to interfere with fitting out new construction were to be given the option of proceeding to Prince Rupert for repairs or making another transpacific voyage before having the work done. Greatly increased fitting out of transport ferries (LST3s) and amenities ships for the Royal Navy had brought on this new stringency. As five Soviet vessels had been taken in for repairs, none of the others could be handled before the end of February $1945 .^{60}$

By then, Soviet ship repairs had spread from Vancouver and Prince Rupert to Victoria reaching the point that the controller could no longer handle all the work requested. Repairs on the west coast had reached an all time high and were being carried out almost exclusively for the U.S.S.R. ${ }^{61}$ "The Russian authorities," reported Carswell, "seem to have an unlimited volume of ship repairs piled up waiting to be carried out, and the more we do in Vancouver, the greater the continuing demands." ${ }^{2}$ On 1 March, the Mutual Aid Board made an additional \$3 million available at Vancouver largely due to "unforeseen repairs to Liberty ships." 63

By the end of the month, Canadian authorities had re-located a considerable portion of Soviet ship repairing to Prince Rupert as repairs to ships on the west coast continued to use all available labour not fully employed on new ship construction. ${ }^{64}$ After approving interim repair bills costing $\$ 772,000$ for just two ships, Carswell advised the Mutual Aid Board's director of administration to put aside repairs to a third 25-year old vessel estimated to take four months and to cost $\$ 350,000$. Repairs were getting more expensive and too many ships requiring minor or running repairs would not receive any in consequence. ${ }^{65}$

With the cessation of hostilities in Europe, relief was in sight. The Canadian view of the Soviet Union had hardened during the first quarter of 1945 and in May, the Mutual Aid Board met and considered at length what its future policy should be. In light of the U.S.S.R.'s agreement to pay for Canadian industrial equipment by a long-term credit, the board declined to pay for any additional ship repair work. ${ }^{66}$ Repairs might be carried out on the SS Shchors, but only if done for Soviet account; no ship arriving after 9 May

59 LAC/ RG 36.21/ 68/ 7-V3-A (pt. 4) Schedule of Russian Ship Repair Programme, attached to W. Dey, manager, BC division, Wartime Shipbuilding Ltd. to D. B. Carswell, 13 December 1944.

60 Ibid. D. B. Carswell to W. Dey, 28 December 1944.

61 LAC/ RG 36.21/ 68/ 7-V3 vol. 10 I. I. Krotov, commercial councillor USSR embassy, to G. R. Heasman, assistant to director of CMAB, 6 February 1945 acknowledging the situation.

$62 \mathrm{LAC/}$ RG 28/ 256/ 196-13-3 report for the period ending 28 February 1945.

$63 \mathrm{LAC/}$ RG 36-21/46 CMAB minutes 1 March 1944.

$64 \mathrm{LAC/}$ RG 28/ 256/ 196-13-3 quarterly report for the period ending 31March 1945.

65 LAC/ RG 36-21/ 69/ 7-VS-71 (1) telegram, D. B. Carswell to Karl Fraser, 30 April 1945.

66 Ibid., G. R. Heasman to Lt. Col. F. N. Timchenko, USSR embassy 3 May 1945; also Smith, Diplomacy of Fear, 75-6, 78-9. 
would be eligible for repairs under mutual aid. ${ }^{67}$ Repairs to Soviet vessels declined substantially thereafter. ${ }^{6}$ Nevertheless, the value of ship repairing work during the abbreviated third year approached the value of the previous full year, reaching $\$ 4,633,000$.

Canadian mutual aid, like American lend-lease, had a strong economic dimension from the outset. Like their American counterparts, Canadian politicians and government officials provided aid to their Allies in return for the beneficiaries promising to follow postwar economic policies that would lead to promotion of employment, production and export of consumer goods, and "the expansion of commerce through appropriate international agreements on commercial policy." 69

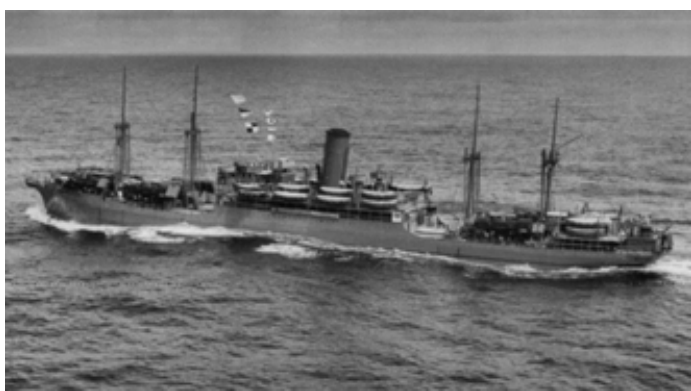

Illustration 7: SS Felix Dzerzhinsky photographed 1 June 1944, 47 46' N $12488^{\prime}$ $W$ by US navy. Sailed once from Vancouver in October 1943. Source: US Navy declassified. North Americans were determined to remove barriers to international trade that they believed had led to depression and war. ${ }^{70}$ Economic motives dominated the evolution of Canada's policy towards another recipient of mutual aid, China, and similar hopes were entertained regarding the Soviet Union. ${ }^{71}$ In September 1942, well before the passage of the Mutual Aid Act, Canada had extended a three-year term credit worth $\$ 10$ million to the Soviet Union, and as a market for Canadian exports of manufactured goods reappeared in January 1944, the Cabinet War Committee approved a recommendation that electrical equipment to the value of $\$ 15$ million be supplied to the U.S.S.R. through a long-term ( 5 to 10 year) credit rather than mutual aid. The Cabinet War Committee's minutes also noted approvingly that Canada needed to underwrite export credit risks, which was something new. ${ }^{72}$ Six months later, on 28 July, Canada introduced the Export Credits Insurance Act to provide for insurance of short-term commercial credits that could only be used to purchase Canadian goods and services. ${ }^{73}$

Economic policy considerations did not remain the sole criterion, however, for

67 LAC/ RG 36.21/ 69/ 7/VS-71 (1) telegram G. R. Heasman to D. B. Carswell 14 May 1945.

$68 \mathrm{LAC/}$ RG 28/ 256/ 196-13-3 quarterly report for period ending 30 June 1945.

69 Quotation is from the War Appropriation (United Nations Mutual Aid) Act (1943) in Soward, Canada in World Affairs, 75; and John W. Holmes, The Shaping of Peace: Canada and the search for world order 1943-1957, Volume 1 (Toronto: University of Toronto Press, 1979), 81.

70 Robert Bothwell, Ian Drummond and John English, Canada Since 1945: Power, Politics, and Provincialism (Toronto: University of Toronto Press, 1981), 80-1.

71 Kim Richard Nossal, "Business as Usual: Canadian Relations with China in the 1940s," Canadian Historical Association, Historical Papers, 1978, 144-5.

$72 \mathrm{LAC/} \mathrm{RG} 2,7 \mathrm{c} / 15$ (reel C-4,876) Cabinet War Committee minutes 20 January 1944.

73 Holmes, Shaping of Peace, 90-1. 
that same month the war cabinet also agreed that Canadian defence arrangements with the United States would depend on the general character of U.S.-U.S.S.R. relations and that maintenance of good relations with both countries was of great importance. ${ }^{74}$ Whether Canada's defence and security policies could proceed hand in hand with its economic policies governing post-war commercial relations with foreign countries remained at issue.

At the same time, there was no let up in mutual aid shipments during the fourth protocol. From April to October 1945 forty-one Soviet ships carried away supplies worth $\$ 46,270,000$ from west coast ports at a rate of nearly six sailings per month. Eleven vessels departed from Vancouver in May and nine, including two each from New Westminster and Victoria, sailed during October. Mutual aid was terminated in September and the last Soviet ship in the programme, SS Djurma, cleared Vancouver on 24 October $1945 .^{75}$

Neither the hardening attitude towards the Soviet Union nor the Gouzenko spy revelations affected Canada's last major gift to the Soviet Union. From the moment of their first arrival in Canada in June 1943, Soviet representatives had requested minesweepers, and, in September 1944, Canada agreed to provide ten vessels to the Soviet navy, which faced a huge problem clearing Arctic waters and the Black Sea of mines. ${ }^{76}$ The minesweepers were not completed at the end of hostilities in Europe, at which time the navy cut back its own requirement. The Mutual Aid Board took over the resulting surplus and was able to provide ten 126-foot wooden, motor minesweepers to the U.S,S.R. ${ }^{77}$ The Board also arranged with the RCN to train nearly 250 Soviet naval officers and ratings who arrived in Toronto and Vancouver to man these ships. ${ }^{78}$ The value of the gift was put at $\$ 5.7$ million. ${ }^{79}$ The minesweepers were an exception to the curtailment of mutual aid, as the board understood they were to be used for their intended purpose, clearing mines after hostilities had ended..$^{80}$ The ships were turned over to the Soviet navy in 1945 and 1946, and reportedly spent nearly two years at work in Russia's northern waters and the Black Sea. ${ }^{81}$

$74 \mathrm{LAC/}$ RG 2, 7c/ 15 (reel C-4,876) Cabinet War Committee minutes, 19 July 1944.

75 LAC/ RG 36.21/vol. 80 Djurma's cargo manifest.

76 Ibid. CMAB minutes 25 September 1944.

77 G. N. Tucker, The Naval Service of Canada, 2 vols. (Ottawa: King's Printer, 1952), 2: 514 gives the specifications, names, and commissioning dates of nine of these vessels. It appears that the tenth ship was delivered from the builder directly to the Soviet navy.

78 LAC/ 36.21/ 68/ 7-V3-11 W. G. Mills, deputy minister DND (Naval Services), to Karl C. Fraser, 7 August 1945 and ibid. 67/ 7-v1 (pt 4) vol. 3 naval messages 21 and 25 November 1945.

79 CMAB, Final Report, 1946 (Ottawa, 1946), 38-9.

$80 \mathrm{LAC} / \mathrm{RG} 36-21 / 46$ CMAB minutes 8 May and 13 August 1945.

81 These ships were unnamed in the Soviet navy, receiving instead commissioning numbers T193 to T-202. According to one news report, the final four ships, all built on the west coast sailed to the Black Sea from New York. "Four Russian Ships Here; Minesweepers built in Canada are en route to Black Sea," New York Times, 1 May 1946, p. 4. 
Canada's provision of aid to the Soviet Union had been characterized by developing harmonious diplomatic relations, at least between governments, and expectation that these could be developed into equally harmonious commercial relations. On ending mutual aid, the Board authorized continuing production of a large amount of industrial equipment for the U.S.S.R., which had undertaken to pay for it. But the arrangements were never completed.

Canada had already fallen into line behind the United States during the summer of 1945, and Igor Gouzenko's revelations in September 1945 that a Soviet spy network was operating across the country brought no new sudden change. Developing commercial relations had already been halted for the foreseeable future. Negotiations over credits failed during the fall. As of 11 November, Canada no longer extended credit and required the Soviet Union to pay cash for all purchases. In the case of wheat, Canada agreed to fill all existing contracts, and the amount scheduled for November shipment went forward on the existing credit basis.

During negotiations with the Canadian minister of finance, Soviet commercial councillor I. I. Krotov expressed regret at the change in the Canadian attitude toward the Soviet Union. It had been most cordial during the mutual aid period, and Krotov regretted the changed relations were due to the small amounts of money involved. No mention was made of Gouzenko or his shocking disclosures. Canada's position was that with the end of mutual aid, the Soviets were attempting to drive inordinately hard bargains, in effect giving no weight to previous mutual aid they had received or to the preferred treatment they had enjoyed. The provision of minesweepers and the payment of living expenses of Soviet naval crews in Canada were conveniently forgotten. ${ }^{82}$ Later in March 1946, the Mutual Aid Board decided that the Soviet government should be billed for all goods that

\begin{tabular}{|c|c|c|c|c|}
\hline \multicolumn{5}{|c|}{ Mutual Aid Disbursements for the USSR, Sept. 1943 - Sept. $1945(\$ 000,000)$} \\
\hline Commodities & $1943-44$ & $1944-45$ & $1945-46$ & Total \\
\hline Aluminum \& Base Metals & 10.772 & 19.411 & 2.180 & 32.363 \\
\hline Agricultural Products & 2.791 & 19.914 & 8.058 & 30.763 \\
\hline Auto and Rail Equipment & 0.702 & 23.663 & 5.869 & 30.234 \\
\hline Electrical \& Tel. Equipment & - & 9.004 & 10.574 & 19.578 \\
\hline Ship Repair \& Naval Vessels & 1.142 & 4.813 & 10.696 & 16.651 \\
\hline Chemical \& Explosives & 4.134 & 5.361 & 2.35 & 11.845 \\
\hline Miscellaneous & 3.74 & 15.438 & 6.643 & 25.821 \\
\hline Totals & 23.281 & 97.604 & 46.37 & 167.255 \\
\hline
\end{tabular}

82 LAC/ RG 25/ 2,526/ 158-40 (PT 4) Secretary of State for External Affairs (i.e. Mackenzie King) to Canadian ambassador to the USSR, 20 November 1945. For further treatment of the trade deadlock see Black, Canada in the Soviet Mirror, 168-9. 
had been shipped after 1 September 1945, but whether Canadians ever collected remains unknown. ${ }^{83}$ Postwar friendly commercial relations remained a long way off as the realities of the cold war swiftly took over.

The above table shows the order by value of goods sent to the U.S.S.R. The largest items over the whole mutual aid period were aluminum and other base metals, followed by wheat, flour and other foodstuffs. Automotive and transport equipment were third, while radio, electrical and telephone equipment were fourth in value. Ship repair and naval vessels followed close behind ${ }^{84}$ Seventy-four different Soviet ships departed Vancouver between August 1943 and October 1945 with Canadian mutual aid cargoes. Most made only a single voyage from Canada to Siberian ports, but twenty-seven made multiple journeys. Fourteen made a second one; six made three; three made four; and four made five departures. Twenty of these ships were Liberty ships, but most Russian vessels were old and in need of much repair. How many of these ships also received extensive work remains unclear, but many did.

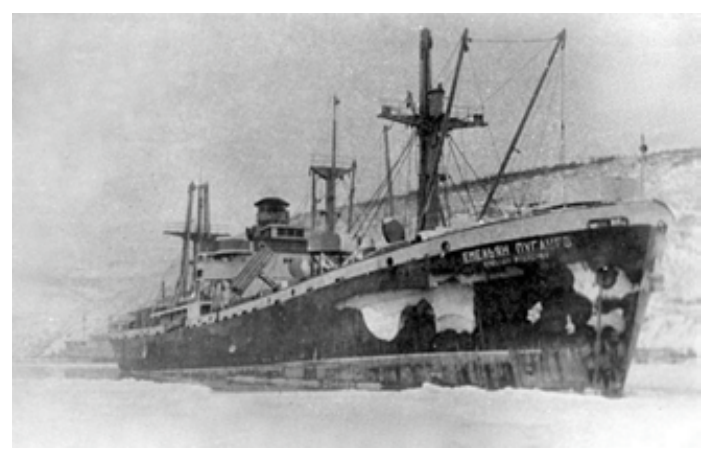

Illustration 8: SS Emilian Pugachev, a Liberty ship that made five voyages from Vancouver to the Soviet Far East between May 1944 and June 1945.

During the war, Canada sent more aid to the Soviet Union than to any other country except Great Britain. The total expenditure of over $\$ 167$ million by the Mutual Aid Board for the U.S.S.R. represented 6.8 per cent of Canada's total mutual aid expenditures of nearly $\$ 2.5$ billion. Great Britain received 85.5 per cent of total expenditures, while the remainder went to several commonwealth countries, China, France and Greece. ${ }^{85}$ According to Robert Bothwell, Soviet aid created something of a paradox. Canadians on the whole being anti-Communist and distrustful of the U.S.S.R., it had to be justified in more than strategic terms. Previously anti-communist politicians stressed that the Russians were worthy allies. ${ }^{86}$ But there had always been something more. From the earliest days, some in the Canadian government had hoped that mutual aid might lead to more enduring postwar commercial relations. It was a disappointing end to a relationship that had once been filled with good will and from which Canada had hoped to develop profitable trade.

Canadian authorities agreed to the Soviet Union's exorbitant demands for ship repair because they understood there was only a certain tonnage available to move

83 LAC/ RG 36-21/ 46 CMAB minutes, 29 March 1946.

84 CMAB, Final Report, 1946, 13-15; also Bryce, Canada and the Cost of World War II, 157.

85 CMAB, Final Report, 1946, 7.

86 Robert Bothwell, The Big Chill: Canada and the Cold War (Toronto: Irwin Publishing, 1998), 9 . 
supplies to the U.S.S.R. by various routes within the framework of world allocation. Keeping old ships afloat regardless of their age was one of the most important services provided by the Canadian Mutual Aid Board, not just to the Soviet Union but also to the Allied cause. ${ }^{87}$

One final feature of repairing Russian ships deserves notice, adding a bizarre note to the Gouzenko affair. Among the last Russian ships to be repaired at Canadian taxpayers' expense were five of the NKVD's prison ships. They had been and continued to be used to transport hundreds of thousands of prisoners to Magadan and the Kolyma gold fields. One received repairs only and four departed Vancouver with the last Canadian mutual aid cargoes after receiving extensive repairs that would allow them to continue their odious tasks until the mid-1950s. ${ }^{88}$

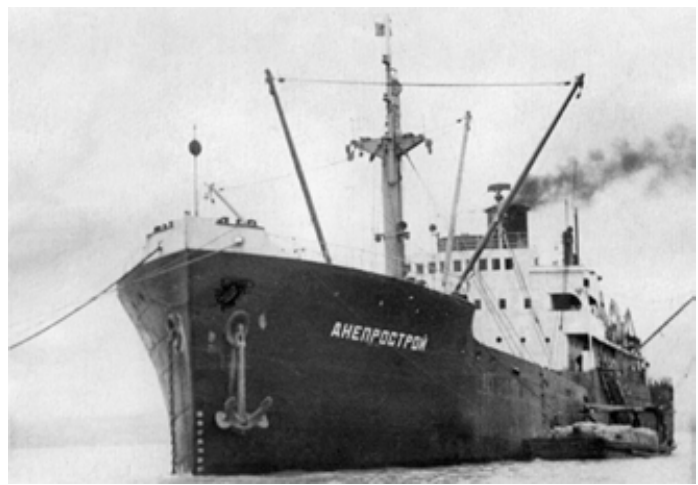

Illustration 9: SS Dnepostroy (ex-Dallas) built in 1919 in the USA; purchased by the NKVD 1936. Photographed off the West Coast in June 1944. Departed Vancouver on 2 October 1945. From a declassified US Navy photo.

The author gratefully acknowledges the support of his research by the Social Sciences and Humanities Research Council of Canada and the Office of Research Services of Queen's University.

87 LAC/ RG 36.21/ 68/ 7-V3 vol. 10 Karl C. Fraser, director of administration CMAB, to W. K. Bennett, executive assistant to C. D. Howe, 21 November 1944.

88 According to Bollinger, Stalin's Slave Ships, 30-6 in 1935 a senior NKVD officer travelled to the Netherlands to purchase three ships including the Yagoda, later Dalstroi (6,948 grt), Djurma (6,908 grt) and Kulu (6,820 grt). Built in the Netherlands between 1917 and 1921, these ships had been laid up during the Depression. Next to be added in 1937 was the world's largest cable-layer, the British-built Dominia re-named Felix Dzerzhinsky (9,273 grt); in 1941, the Swedish-built Sovetskaya Latvia (5,629 grt) was added. Dalstroi departed Vancouver in August 1945 after being dry-docked and repaired; she did not carry a mutual aid cargo.; Kulu made two departures from Vancouver on 25 May and 11 August 1945, and Sovetskaya Latvia departed Vancouver on 19 September 1945. Djurma, also repaired, was the last Russian ship to depart Vancouver under the mutual aid programme on 24 October 1945. A fifth NKVD vessel, Dneprostroy, departed Vancouver on 5 September 1945. See LAC/ RG 36.21/ vol. 80 cargo manifests. Aleksandr I. Solzhenitsyn, The Gulag Archipelago; 1918-1956, An Experiment in Literary Investigation Translated by Thomas P. Whitney 3 vols. (New York: Harper \& Row, 1974-78), 1: 581-2 describes how in May 1938 three of the ships, Dzhurma, Kulu and Dneprostroi (sic) were caught in the ice on their way from Vladivostok to Magadan. After suffering a week on board the prison ships, the prisoners, three to four thousand in each vessel, were forced to disembark and walk across the frozen sea to the camps. 


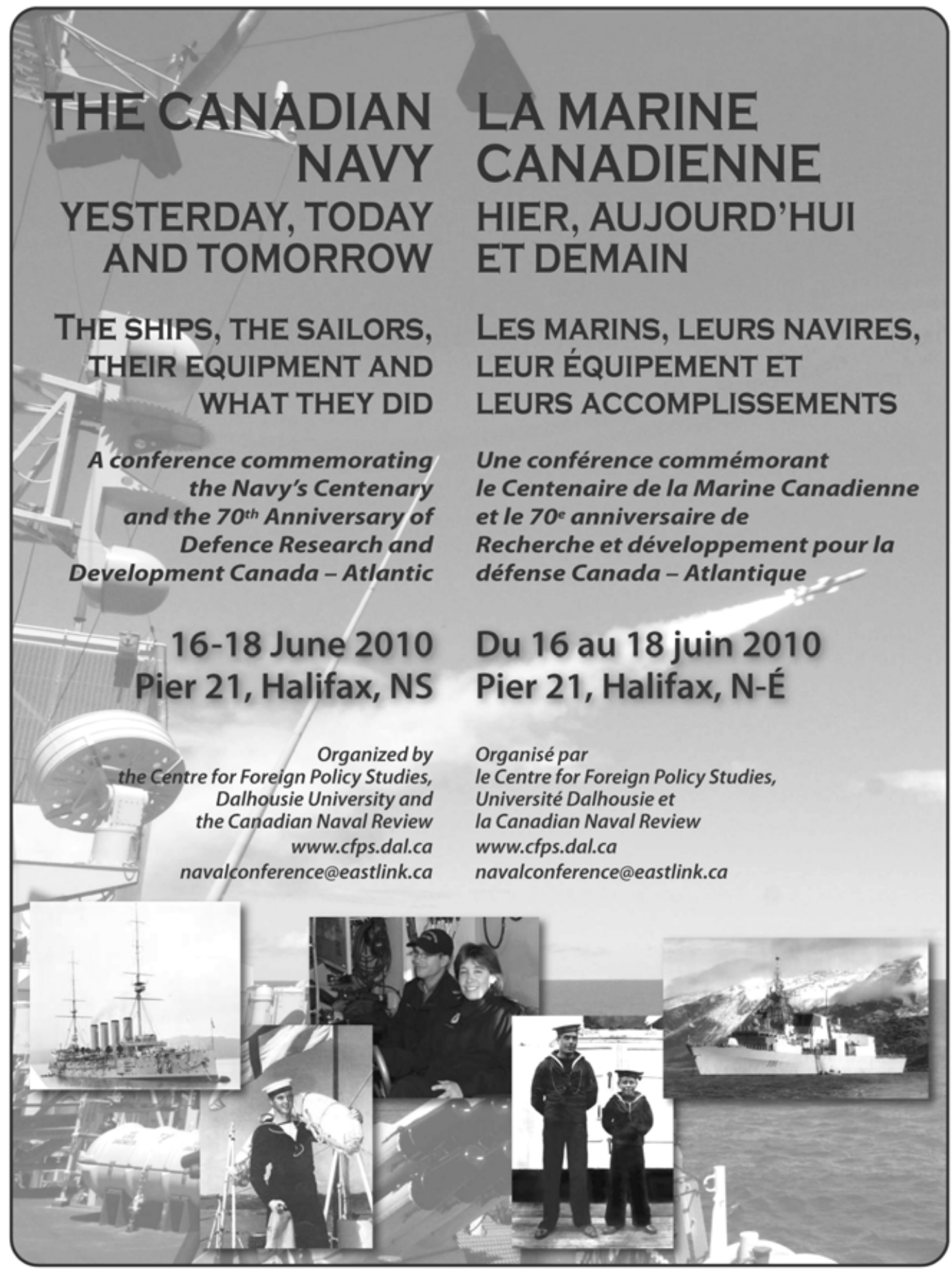

